\title{
Neohyadesia microtricha (Acari: Astigmata: Algophagidae): a new species from the sub-Antarctic
}

Accepted: 30 June 2000

\begin{abstract}
The sub-antarctic mite genus Neohyadesia (Acari: Astigmata) is known from two described taxa: $N$. signyi from Signy Island (South Orkney Islands, South Atlantic Province), and a subspecies, N. s. punctulata from Ile Kerguelen (South Indian Province). This paper describes a second species distinguishable by, in particular, cuticular microtrichae covering the dorsal surface. The new species, $N$. microtricha sp. nov., has a similarly disjunct sub-antarctic distribution, occurring on both Marion (SIP) and South Georgia (SAP) islands. A systematic synopsis of the sub-antarctic algophagine mites is given.
\end{abstract}

\section{Introduction}

The genus Neohyadesia was proposed by Hughes and Goodman (1969) for a new species, N. signyi, collected from fresh to brackish water pools on Signy Island, South Orkney Islands (Hughes and Goodman 1969; Schenker 1986). Fain (1974) proposed a new subspecies, N. signyi punctulata, for a single male specimen collected from halophytic vegetation on Ile Kerguelen. Neohyadesia, Algophagus Hughes 1955 and Algophagopsis Fain and Johnston 1975, constitute the Algophaginae Fain 1974, one of two subfamilies of the Algophagidae Fain 1974, and the only one represented in the sub-Antarctic.

During a recent survey of the terrestrial invertebrates of Marion Island (see Marshall et al. 1999), specimens of Neohyadesia were collected from boulder beach sedi-

D. J. Marshall ( $ه)$

Department of Zoology, University of Durban-Westville, P/Bag X54001, Durban,

4000, South Africa

e-mail: marshall@pixie.udw.ac.za

B. M. OConnor

Museum of Zoology, University of Michigan,

Ann Arbor, Michigan, USA

P. J. A. Pugh

British Antarctic Survey, Madingley Road,

High Cross, Cambridge, UK ments. These mites differed markedly from $N$. signyi in having the dorsal integument ornamented with microtrichae. The Marion Island Neohyadesia specimens, however, compare favourably with a series of specimens collected from South Georgia in 1962 and sent to one of us (B. M. OC.) by the late Dr. Preston Hunter. Specimens from Marion Island tend to be slightly larger and have slightly longer body setae than those from South Georgia, but there is mostly overlap in measurements and sample sizes are relatively small, so we regard these populations as conspecific. This new species from Marion and South Georgia is described herein.

\section{Materials and methods}

Mites were collected from sediments under beach boulders and preserved in $70 \%$ ethanol. In the laboratory, specimens were cleared in lactic acid and mounted in Hoyer's medium. Specimens were collected at the following localities: Marion Island, Trypot beach (4654'S, 37³5'E), May 1996 and May 1998, by R. Mercer (type locality); South Georgia, Bird Island, Stinker Cape $\left(54^{\circ} 00^{\prime} 16^{\prime \prime} \mathrm{S}\right.$, $\left.38^{\circ} 03^{\prime} 35^{\prime \prime} \mathrm{W}\right), 3$ April and 23 May 1963, by H. B. Clagg. In the following description, nomenclature for idiosomal chaetotaxy follows Griffiths et al. (1990); leg chaetotaxy follows Grandjean (1939). All measurements are given in micrometres $(\mu \mathrm{m})$ and are given as follows: holotype female, range of five paratype females, range of five paratype males (three from Marion and two from South Georgia). Because males and females are largely similar except for primary genitalic characters, descriptions are combined. The holotype will be deposited in the Natural History Museum, London, United Kingdom; paratypes in that institution and in the University of Michigan Museum of Zoology, Ann Arbor, Michigan, USA, and the Plant Protection Research Institute, Pretoria, South Africa.

\section{Results}

Description

Neohyadesia microtricha sp. nov. (Figs. 1, 2, 3, 4)

Holotype: female, Marion Island (idiosomal length $420 \mu \mathrm{m})$. 
Paratypes: four males, Marion Island (idiosomal length 416-440 $\mu \mathrm{m})$; five females $(468-491 \mu \mathrm{m})$, five males $(360-518 \mu \mathrm{m})$, South Georgia Island.

Diagnosis: $N$. microtricha sp. nov. differs from $N$. signyi and $N$. s. punctulata in the following characters: (1) dense microtrichae lateral to propodosomal shield and covering the dorsum (cuticle smooth or pitted in N. signyis. lat.); (2) setae $c l$ and $d 1$ as long or longer than their separating distance (in N. signyi and N. s. punctulata setae $c l$ and $d l$ shorter than separating distance).

Adult. Gnathosoma. Chelicerae (Fig. 2c) stout, chelate-dentate, length $(76,76-83,69-74)$, tips of digits simple. Subcapitulum (Fig. 2b) quadrate, length from base to tip of palp $(68,71-76,60-74)$, bearing ventral subcapitular setae at base of rutella, palpal supracoxal seta absent. Rutella deeply bilobed. Palp with two dorsal setae, ventral seta absent; palp tarsus with thin solenidion and stout ventral eupathid.

Dorsum: integument generally unsclerotized, but with a small sclerite between the $s i$ and $c 2$ setae, in addition to the sclerotized propodosomal shield and axillary organ structures. Integument with a pattern of elongate, tapering microtrichae minimally consisting of a pair of patches lateral to propodosomal shield and a large patch in posterior lateroventral region. Most adults with microtrichae covering unsclerotized cuticle of entire dorsum (one male from South Georgia exhibiting minimum pattern). Microtrichae ranging from 5 to $15 \mu \mathrm{m}$ in length; those in dorsocentral region often appearing flattened, with ovoid bases resembling punctations. Sejugal furrow absent. Propodosomal shield narrow (39-46) and long (115-138), extending from internal vertical setae ( $v i)$ to anterior of internal scapular setae (si). External vertical setae (ve) not observed but alveoli distinct on lateral edge of propodosomal shield. Supracoxal $(s c x)$ setae present. Axillary organs [termed supracoxal fossae in Hughes and Goodman (1969)], typical for algophagids, restricted to dorsal surface laterad of propodosomal shield. Bordering sclerite of axillary organ extends latero-anteriorly to middle of propodosomal shield. Additionally, a pair of semicircular sclerites occurs dorsally of coxae II. Cupules $i a$, im and ip, and openings of opisthonotal glands ( $\mathrm{gla}$ ) distinct (Fig. 1a).

Dorsum with 15 pairs of setae: verticals (vi) arise from the vertex of propodosomal shield. Internal scapulars (si) slightly shorter than external scapulars (se). Dorsal setae are either thinly filiform, or short stout spines ( $c p, f 2, h 1$ and $p s 2$; Fig. 1a). Setal lengths similar in both sexes and are as follows (Marion Island specimens tend to be larger): vi (34, 16-21, 18-34), se (71, 62-76, 62-81), si (63, 51-60, 51-67), c1 (81, 37-69, 35-91), c2 (97, 78-87, 78-106), c3 (81, 90-108, 83-108), $c p(20,14-16,16-24), d 1(91,58-85,76-102), d 2(95$, 58-81, 69-93), el [87 (Marion female), 25-53 (South Georgia females), 87-95 (Marion males), 23-30 (South Georgia males)], e2 (106, 76-99, 81-112), f2 (20, 16-23, 18-25), hl (20, 12-14, 12-20), psl [112 (Marion female), 55-87 (South Georgia females), 108-120 (Marion males), 55-62 (South Georgia males)], ps2 (20, 16-23, 16-21).

Venter. Four pairs of ventral setae $h 2, h 3, p s 3, a d 3$ and one pair of cupules (ih) in female, but ad 3 absent in male (Figs. 1b, 2). Setae $h 3$ characteristically long, and $h 2$ a short stout spine. Setal lengths are as follows: $h 2$ (20, 21-25, 21-26), h3 (199, 230-246, 217-253), ps3 (49, 39-55, 41-53), ad3 (female only) (30, 28-35). Four pairs of thinly filiform coxal setae and one pair of genitals $(g)$ in both sexes, lengths as follows: $1 a(32,35-39$, 26-37), 3a (26, 18-28, 16-24), 3b (35, 30-37, 35-41), 4a $(49,28-35,30-35), g(30,25-30,16-25)$. Apodemes moderate to lightly sclerotized and excepting I are free
Fig. 1A, B Neohyadesia microtricha sp. nov.. A Dorsum of female. B Venter of female. Scale bar indicates $200 \mu \mathrm{m}$
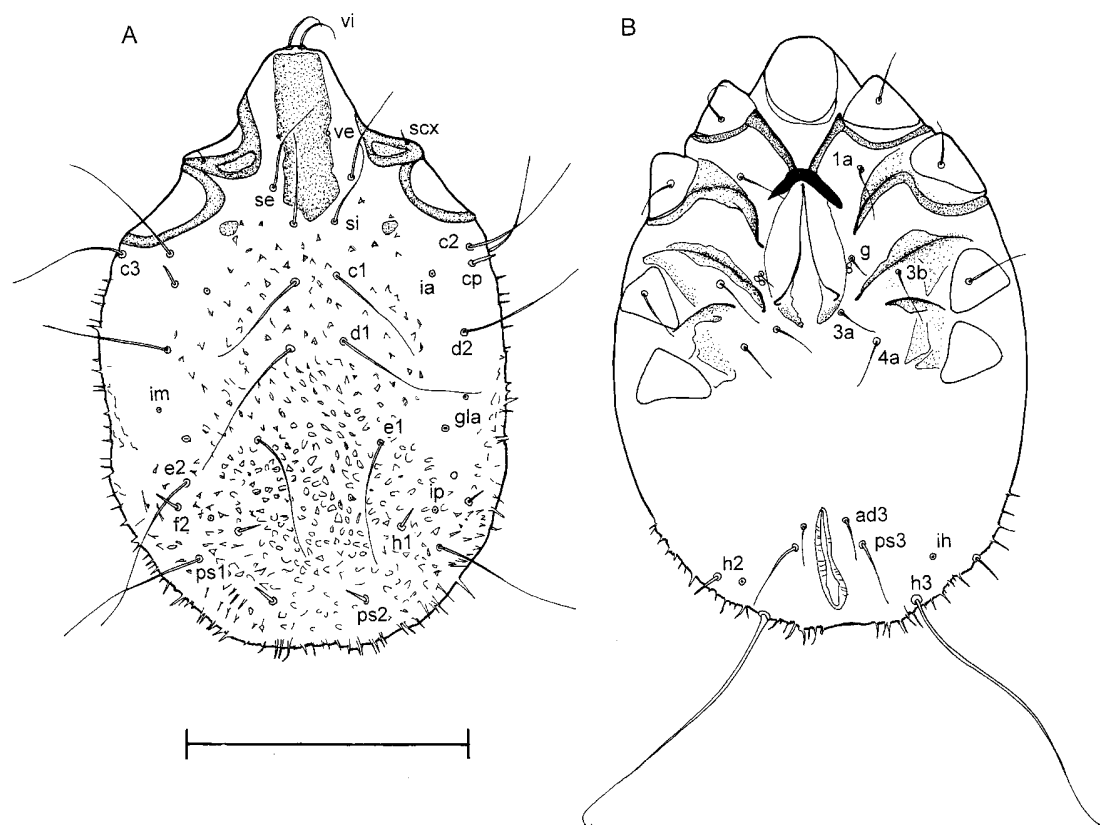
Fig. 2A-C Neohyadesia microtricha sp. nov.. A Male venter. Scale bar indicates $100 \mu \mathrm{m}$. B Subcapitulum and palps and C chelicera. Scale bar indicates $40 \mu \mathrm{m}$

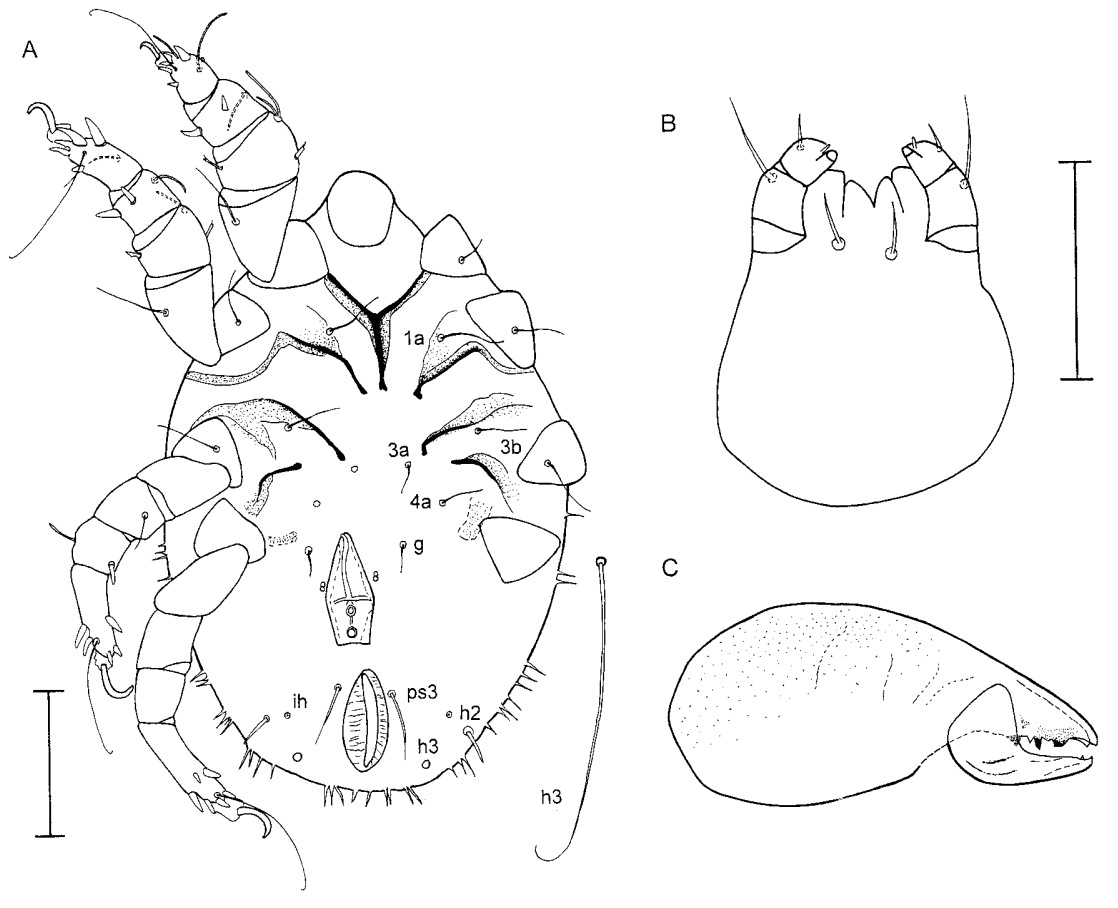

medially. In females, coxal field I apodemes fuse to epigynial apodeme (Fig. 1b) while, in males, apodemes I fuse to form a sternum (Fig. 2). Female ovipore large and elongated extending from level of setae $l a$ to near $3 a$, with ovipore anterior of coxal fields IV. Two pairs of small genital papillae just posterior to genital setae in female, but clearly posterior to them in male. Male genital organs concealed by triangular plate. Aedeagus an anteriorly directed tube, largely straight but distinctly hooked distally, length (including basal piece) $58-71$.

Legs. Typically possess flexible, membranous pretarsus with empodial claw. Claws of legs I and II slightly smaller than those of legs III and IV, with male claw I distinctly smaller than the others. Chaetotaxic formula (tarsus, tibia, genu, femur, trochanter) typical for Neohyadesia: leg I, 9.2.2.1.1; leg II, 9.2.2.1.1; leg III, 7.1.1.0.1; leg IV, 8.1.0.1.0. Solenidiotaxy: leg I, $2+$ famulus.1.2.0.0; leg II, 1.1.1.0.0; leg III, 0.1.1.0.0; leg IV, 0.1.0.0.0. (Figs. 3, 4).

Leg I. Terminal tarsal spines $p$ and $q$ possess a small medial fork, which is also seen on other legs. Dorsal setae $d$ and $e$, and ventral setae $s$ and $w a$, spinous, lateral seta $r a$ long, hooked apically, $l a$ and $f$ thinly filiform. Basal solenidion $\omega 1$ longer than other solenidia, $\omega 3$ apical; $\omega 2$ absent. Large, spinelike famulus arises near base of $\omega 1$. Tibia with $g T$ and $h T$ stout spines, solenidion $\phi$ short. Genual setae $c G$ and $m G$ thick, forked and serrated, respectively; solenidion $\sigma^{\prime}$ subequal in length to $\sigma^{\prime \prime}$. Setation of leg II similar to leg I, but solenidion $\omega 3$, and famulus, of tarsus, and one solenidion of genu missing. Setation of legs III and IV typical for genus. Tarsus III with only basal seta $w$, whereas both setae $r$ and $w$ occur on tarsus IV.

\section{Discussion}

Specimens from the Marion Island and South Georgia populations differed in the absolute lengths of idiosomal setae $e l$ and $p s l$, with individuals from South Georgia having distinctly shorter setae. However, the longer, filiform dorsal setae were quite variable in length in both populations, and since sample sizes from both populations were small, we regard the differences in these two setae as indicative of intraspecific variation.

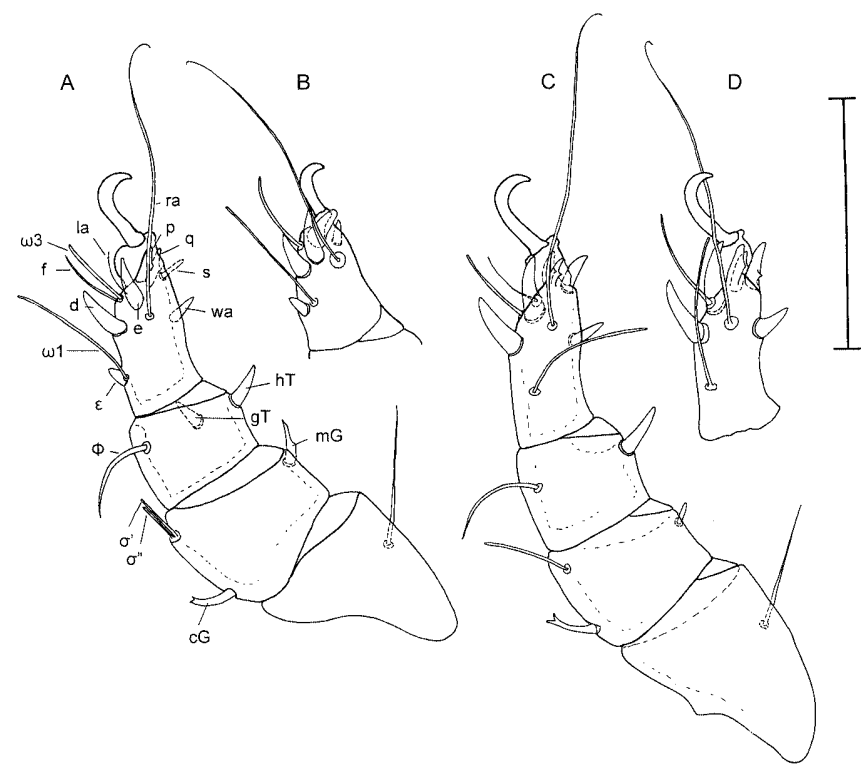

Fig. 3A-D Neohyadesia microtricha sp. nov.. A Leg I female, B tarsus I male, C leg II female, and D tarsus II male. Scale bar indicates $80 \mu \mathrm{m}$ 


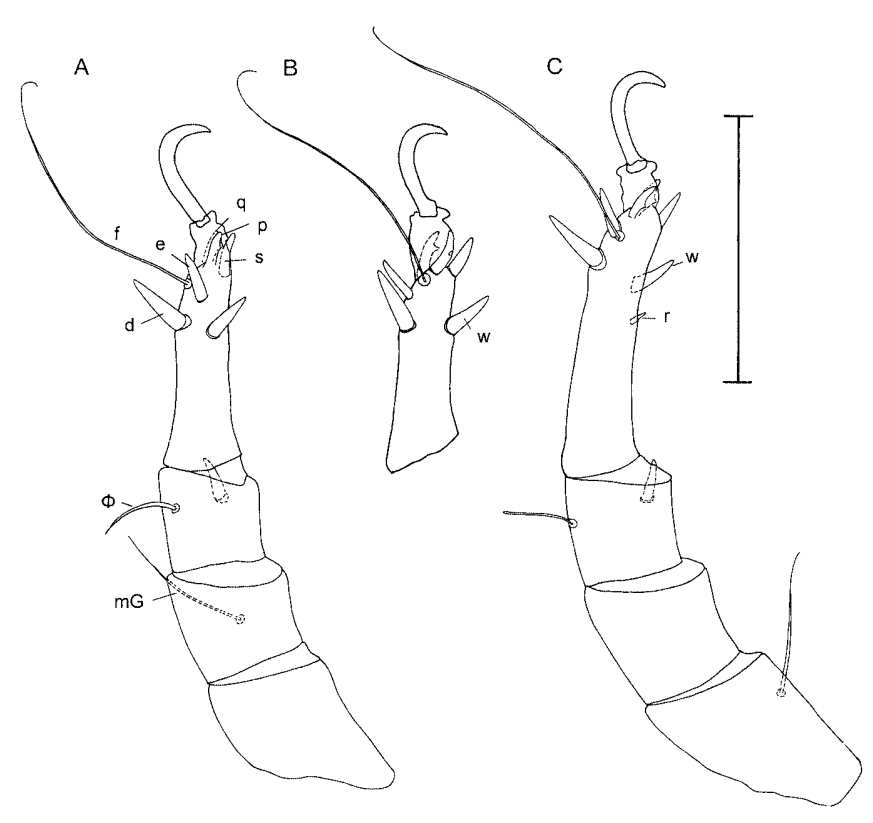

Fig. 4A-C Neohyadesia microtricha sp. nov.. A Leg III female, B tarsus III male and C leg IV female. Scale bar indicates $80 \mu \mathrm{m}$

Hughes and Goodman (1969) originally distinguished Neohyadesia from Algophagus by the following characters: (1) apodemes II in male are not fused; (2) males lacking "genital sense organs" (genital papillae); (3) male genital folds replaced by a hinged plate; (4) solenidion omega $2(\omega 2)$ missing from tarsus I; and (5) ventro-terminal spines $p$ and $q$ forked. In their key to algophagid genera, OConnor and Moser (1985) used only the reported presence of external vertical setae to separate Neohyadesia. Examination of the holotype and recently collected specimens of $N$. signyi (six males and eight females by Matt Edworthy in February 2000, for deposition in Natural History Museum, London, UK), as well as the new species described above, and comparison of these taxa with subsequently described algophagine species, allow us to rediagnose the genus. Of the character states noted above: (1) is no longer diagnostic of Neohyadesia as the male apodemes are not fused in Algophagus pennsylvanicus and Algophagopsis pneumatica. They are fused only in sub-antarctic Algophagus species. Character state (2) is not diagnostic as the genital papillae were overlooked by the original describers. They are reduced but still present in Neohyadesia. Character state (3) is not diagnostic as all algophagine males have a relatively large, sclerotized aedeagus and supporting structures (the "hinged plate" of Hughes and Goodman). The genital valves (folds of Hughes and Goodman) are reduced in all these taxa. Character state (4) is not diagnostic as solenidion $\omega 2$ is absent in Algophagopsis as well as Neohyadesia. Character state (5) remains diagnostic, as the forked condition of tarsal setae $p$ and $q$ remains unique to
Neohyadesia. Finally, the holotype of $N$. signyi and all specimens of $N$. microtricha actually lack external vertical setae. The structures noted by Hughes and Goodman are actually just the alveolar vestiges of these setae, which are lacking in all other Algophagidae as well as all other families of Hemisarcoptoidea (sensu OConnor 1982).

In addition to the form of tarsal setae $p$ and $q$, there are other character states of Neohyadesia which are diagnostic: (1) the fusion of the epigynial apodeme with the ends of the apodemes of coxae I in the female (epigynial apodeme unfused and coxal apodemes fused to form sternum in other algophagines); (2) seta $d$ of tarsi I-II in the form of a large spine (seta $d$ I-II thin in other algophagines); (3) restriction of the axillary organs to a completely dorsal position (axillary organs extending at least somewhat ventrolaterally in other algophagines). On the basis of these derived character states, we continue to regard Neohyadesia as a valid genus.

Acknowledgements Richard Mercer (University of Pretoria) kindly provided the material from Marion Island, the late Dr. Preston Hunter (University of Georgia), that from South Georgia Island, and Matt Edworthy (British Antarctic Survey) provided recently collected specimens of $N$. signyi. This article was prepared during a study leave by D.J.M. to the British Antarctic Survey, Cambridge, United Kingdom, supported by a Commonwealth Fellowship (Association of Commonwealth Universities), and to the University of Michigan, United States, supported by the South African National Research Foundation (NRF). The South African Department of Environmental Affairs and Tourism (DEA\&T) provided financial support through the principal grantholder Prof. Steven Chown, and logistical support for excursions to Marion Island.

\section{References}

Fain A (1974) Acariens récoltés par le Dr. J. Travé aux iles subantarctiques. I. Familles Saproglyphidae et Hyadesidae (Astigmates). Acarologia 16: 684-708

Grandjean F (1939) La chaetotaxie des pattes chez les Acaridiae. Bull Soc Zool Fr 6: 50-60

Griffiths DA, Atyeo WT, Norton RA, Lynch CA (1990) The idiosomal chaetotaxy of astigmatid mites. J Zool 220: 1-32

Hughes AM, Goodman BJA (1969) Neohyadesia signyi (Hyadesidae: Acarina): a new genus and species from Signy Island, South Orkney Islands. Br Antarct Surv Bull 22: 39-48

Marshall DJ, Gremmen NGM, Coetzee L, OConnor BM, Pugh PJA, Theron PD, Ueckermann EA (1999) New records of Acari from the sub-antarctic Prince Edward Islands. Polar Biol 21: $84-89$

OConnor BM (1982) Acari: Astigmata. In: Parker S (ed) Synopsis and classification of living organisms, vol 2. McGraw-Hill, New York, pp 146-169

OConnor BM, Moser JC (1985) Phylogenetic relationships of the Algophagidae (Acari: Astigmata), with descriptions of a new subfamily, genus and species. Ann Entomol Soc Am 78: 783-789

Schenker R (1986) Biological and ecological notes on Neohyadesia signyi (Acari; Astigmata). Br Antarct Surv Bull 70: 85-91 